\title{
Habitat use by the Antillean manatee (Trichechus manatus) during an extreme dry season in an urban lake in Tabasco, Mexico
}

\author{
Helda Herenia Ramírez-Jiménez ${ }^{1}$, León David Olivera-Gómez ${ }^{2^{*}}$ and Horacio de la Cueva \\ ${ }^{1}$ El Colegio de la Frontera Sur, Unidad Chetumal, Av. Centenary Km 5.5, CP. 77014, Chetumal. Quintana Roo, Mexico. Email: \\ theryta hh@yahoo.com (HHRJ). \\ ${ }^{2}$ Universidad Juárez Autónoma de Tabasco. División Académica de Ciencias Biológicas, Km 0.5 carretera Villahermosa-Cárdenas, \\ CP. 86039, Villahermosa. Tabasco, México. Email: leon olivera@yahoo.com.mx (LDO). \\ ${ }^{3}$ Centro de Investigación Científica y de Educación Superior de Ensenada. Departamento de Biología de la Conservación, Carretera \\ Ensenada-Tijuana No. 3918, Zona Playitas, CP. 22860, Ensenada. Baja California, México. Email: cohevolution@gmail.com (HC). \\ *Corresponding author
}

There are three important manatee areas in Mexico: the coasts of the State of Quintana Roo; the freshwater systems within the lower basin of the Grijalva-Usumacinta rivers, which host the largest manatee population; and the rivers of central and southern Veracruz. The Antillean manatee (Trichechus manatus manatus) is a threatened species throughout its range. In the Grijalva-Usumacinta region, two of the current threats to manatees are the effects of extremely dry periods and geographical isolation. The objective of the study was to evaluate the behavior and habitat use of the landlocked manatee population inhabiting Laguna de las llusiones, Villahermosa, Tabasco, under fortuitous dry conditions, to conduct an evaluation and implement a monitoring plan for landlocked manatees. In this work, we gathered information on the differential use of the lake, and on whether this use is related to the known habitat characteristics that govern the distribution of manatees. Using VHF tags, we followed the activities of four manatees (three females and one male) to characterize and quantify four behaviors, namely feeding, resting, exploring, and traveling, between April and August 2007. We built Kernel polygons for the 25, 50, 75, and $95 \%$ of the utilization distribution (UD). We modeled the habitat using a binary logistic regression and explored the association between the tagged manatees using Cole's simple coefficient of association. Manatees were concentrated mainly to the northeast of the lake. The best feeding logistic model included depth, distance to the the shore, tree cover, and wind speed (Table 1), and yielded differences between periods $(\mathrm{H}=9.85, P=0.007$, Figure 5). The logistic models fit poorly for resting, exploring, and traveling (Table 1). The resting model included distance to the the shore, tree cover, and company, and yielded differences between periods $(H=6.68, P=0.035)$. Traveling included depth, cloud cover, and human activities, and yielded differences between periods $(H=7.55, P=0.023)$. Exploration included depth and company, and did not differ between periods $(H=1.55, P=0.461)$. We had the opportunity to assess these behaviors under dry conditions, and our findings are not necessarily applicable to the rainy season. The northern portion of the lake is an embayment connected to the central zone by a $50 \mathrm{~m}$-wide shallow channel, which limited the movement of manatees. Higher food availability and stress avoidance might make manatees choose this area. Feeding was better modeled by the habitat characteristics included in the study. Feeding increased slightly in the evenings. Exploring and traveling were the behavior types observed most frequently in manatees; maybe they were moving across food patches or known areas. Manatee social encounters are reported as short-term and sporadic, but in this study manatees were observed in groups during nearly half of the observation time. When the availability of grasses and aquatic plants is low, manatees increase their consumption of other food items like mango fruits. Based on the findings reported here and under dry conditions, habitat enrichment will be helpful for this landlocked manatee population and those in other areas where seasonal contrasts is observed.

En México existen tres áreas importantes de distribución para el manatí: las costas del estado de Quintana Roo, los sistemas de agua dulce en la cuenca baja de los ríos Grijalva-Usumacinta y los ríos del centro y sur de Veracruz. El manatí Antillano (Trichechus manatus manatus) es una especie amenazada en toda su distribución. En la región Grijalva-Usumacinta se albergan las poblaciones más grandes de manatí y se reconocen dos problemas ecológico-ambientales como es el efecto de la sequía prolongada y el aislamiento geográfico de las poblaciones. El objetivo de este trabajo fue evaluar el comportamiento y uso de hábitat de la población de Laguna de las llusiones, Villahermosa, Tabasco, bajo una sequía fortuita, para implementar un plan de monitoreo y evaluación de poblaciones aisladas de manatíes. Con esta investigación se obtiene información del uso diferencial de la laguna y si este uso se relaciona con características del hábitat que determinan su distribución. Mediante el uso de radiotransmisores se dio seguimiento de actividad a tres hembras y un macho, para caracterizar y cuantificar sus comportamientos: alimentación, descanso, exploración y desplazamiento en los meses de abril y agosto 2007. Se realizaron modelos de regresión logística de la ocurrencia de las conductas en relación a características del hábitat y polígonos de distribución de uso (U. D.) de 25, 50, 75 y 95 \%. Para explorar la asociación entre los manatíes marcados se utilizó el coeficiente simple de asociación de Cole. La ocurrencia se concentró al noreste de la laguna. El mejor modelo logístico de alimentación incluyó profundidad, distancia a la orilla, cubierta arbolada, y viento (Tabla 1), difiriendo entre horarios (H = $9.85, P=0.007$, Figura 5). Los modelos de otros comportamientos tuvieron poco ajuste (Tabla 1). El modelo del descanso incluyó distancia a la orilla, cobertura arbolada y compañía, difiriendo temporalmente $(H=6.68, P=0.035)$. El desplazamiento incluyó profundidad, nubosidad y actividad humana, difiriendo entre periodos $(\mathrm{H}=7.55, P=0.023)$. La exploración incluyó profundidad y compañía, sin diferencia temporal ( $\mathrm{H}=1.55$, $P=0.461)$. El brazo norte de la laguna se conecta a través de un canal somero, que en secas puede limitar el movimiento de los manatíes. Mayor disponibilidad de alimento en secas y evasión del estrés pueden llevar a los manatíes a esta área. La exploración y desplazamiento fueron los comportamientos más frecuentes, quizá moviéndose entre parches de alimento o entre áreas conocidas. Casi en la mitad de las observaciones los manatíes estuvieron acompañados. Cuando hay baja disponibilidad de pastos o vegetación acuática, los manatíes usan alimentos alternativos. El enriquecimiento del hábitat, sería muy útil para esta y otras poblaciones aisladas.

Keywords: behavior; habitat modeling; landlocked populations; management requirements; resource availability; spatial distribution.

C 2017 Asociación Mexicana de Mastozoología, www.mastozoologiamexicana.org 


\section{Introduction}

There are three key manatee distribution areas in Mexico: the river systems in the southern Gulf of Mexico (Tabasco, northern Chiapas and southwestern Campeche); the coast of Quintana Roo, mainly in the central and southern areas, and the low portions of rivers in central and southern Veracruz (CONANP 2010). The lower basin of the Grijalva and Usumacinta rivers is believed to host the largest manatee population in Mexico (Lefevre et al. 2001; Marsh et al. 2012).

The Antillean manatee (Trichechus manatus manatus) is considered a species endangered of extinction throughout its distribution range (Self-Sullivan and Mignucci-Giannoni 2008). The Mexican Official Standard lists the manatee in this same category (Mexican Official Standard NOM059-SEMARNAT-2010, Official Journal of the Federation 2010). Manatees face various problems, including an extensive historical hunting that still persists, mainly for subsistence consumption (Smith-Cavros et al. 2012). Other issues are the deaths resulting from the interaction with human activities, habitat loss and alteration of wilderness areas associated to changes in land use for agriculture, livestock raising, and rural or urban development (CONANP 2010). An issue that is unique to this species is the partial or total isolation of local populations due to natural or anthropogenic changes in the topology of the Mexican river systems (CONANP 2010; Estrada-Loreto et al. 2013). The implementation of a monitoring plan for these landlocked populations requires assessing their behavior and habitat use. Decisionmakers, authorities that manage conservation aspects, need a scientific support to plan and execute management initiatives on those populations (CONANP 2010). One such isolated population of T. m. manatus inhabits Laguna de las Ilusiones in Villahermosa, Tabasco, Mexico, a city with a human population of 64,000 inhabitants (INEGI 2010). In this lake, the protection of the manatee population is a top priority, but efforts to characterize it have been made only in the

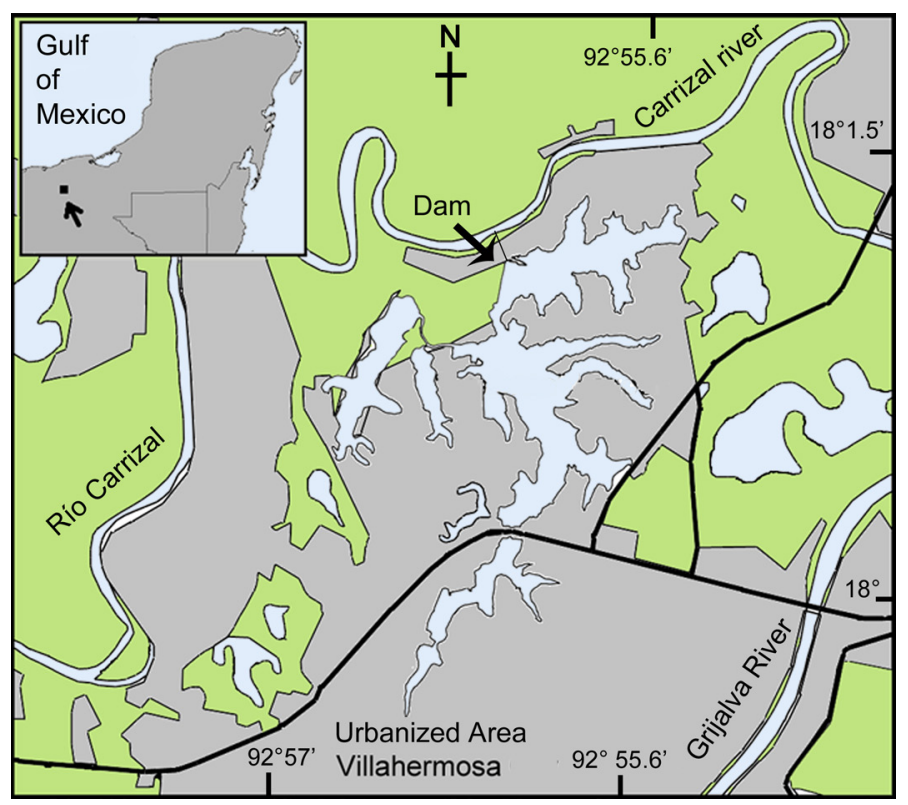

Figure 1. Laguna de las Ilusiones, in the city of Villahermosa, Tabasco, Mexico. past decade (Pablo-Rodríguez and Olivera-Gómez 2012). The estimated population size of manatees in the lake is 18 to 39 individuals (Pérez-Garduza 2013).

Knowledge about habitat use by the Antillean manatee (T. m. manatus) in the landlocked environment of Laguna de las llusiones, coupled with the atypical drought conditions under which this study was conducted, allowed us to document the general behavior of the species, and is a useful model for the development of management techniques.

\section{Materials and Methods}

Study area. Laguna de las llusiones (Figure 1) is an enclosed lake, irregular in shape, with a water mirror that stretches across approximately 260 hectares. It is a shallow water body, with depths that do not reach $5 \mathrm{~m}$, mainly of less than $3.5 \mathrm{~m}$. This lake is located within the city of Villahermosa, Tabasco (17 $59^{\prime} 22^{\prime \prime}, 18^{\circ} 01^{\prime} 22^{\prime \prime} \mathrm{N}$, $-92^{\circ} 55^{\prime} 20^{\prime \prime},-92^{\circ} 56^{\prime} 40^{\prime \prime}$ $\mathrm{W}$, at $10 \mathrm{~m}$ ). The lake is a State of Tabasco's Protected Natural Area (Official Journal of the State of Tabasco, February 3, 1995). Until the early 1980s, it was connected to the Carrizal river, a tributary of the Grijalva river, but the connections were blocked as a result of urban development. Today, a small lock regulates the water level in the lake, allowing a partial flow toward the Carrizal river (INEGI 2010).

The climate in the area is warm and humid, with an annual temperature range of $24^{\circ} \mathrm{C}$ to $28^{\circ} \mathrm{C}$ and precipitation between 1,500 and 2,000 mm/year (INEGI 2010). Soils in the region are Cenozoic sedimentary and fluvisols, which promote the growth of wetland vegetation (INEGI 2010). Wetland vegetation is actively controlled by local environmental authorities and a large part of the lake shores have been severely modified as a result of urban development.

Tagging and tracking. Four manatees, including three females and one male $(195,203,285$ and $180 \mathrm{~cm}$ in straighline total length) were captured momentarily and VHF transmitters (Telenax, Mexico, TX-345Y) with frequencies between 164 and $165 \mathrm{MHz}$ were affixed to them. The tagging system for manatees with VHF transmitters was designed in Florida (Rathbun et al. 1987), where it has been used extensively (Deutsch et al. 2003; Reep and Bonde 2006; Gannon et al. 2007); furthermore, it has been used successfully in the Mexican Caribbean coasts (CastelblancoMartínez et al. 2013) and in fluvio-lacustrine systems of Tabasco (Morales-López et al. 2012). The use of telemetry to document the behavior has also been reported for other large aquatic vertebrates such as the dugong (Sheppard et al. 2010). The manatees were captured and tagged by experienced personnel, following a standard protocol, with the use of 4-inch mesh-size silk purse seines (Morales-López et al. 2012), and under a license issued by the Mexican environmental authorities (SGPA/DGVS/01103/07). The tracking of animals was carried out between April and August 2007.

For the tracking sessions, the day was divided into three observation periods: $6: 00$ to $12: 00 \mathrm{~h}, 12: 00$ to $18: 00 \mathrm{~h}$ and 


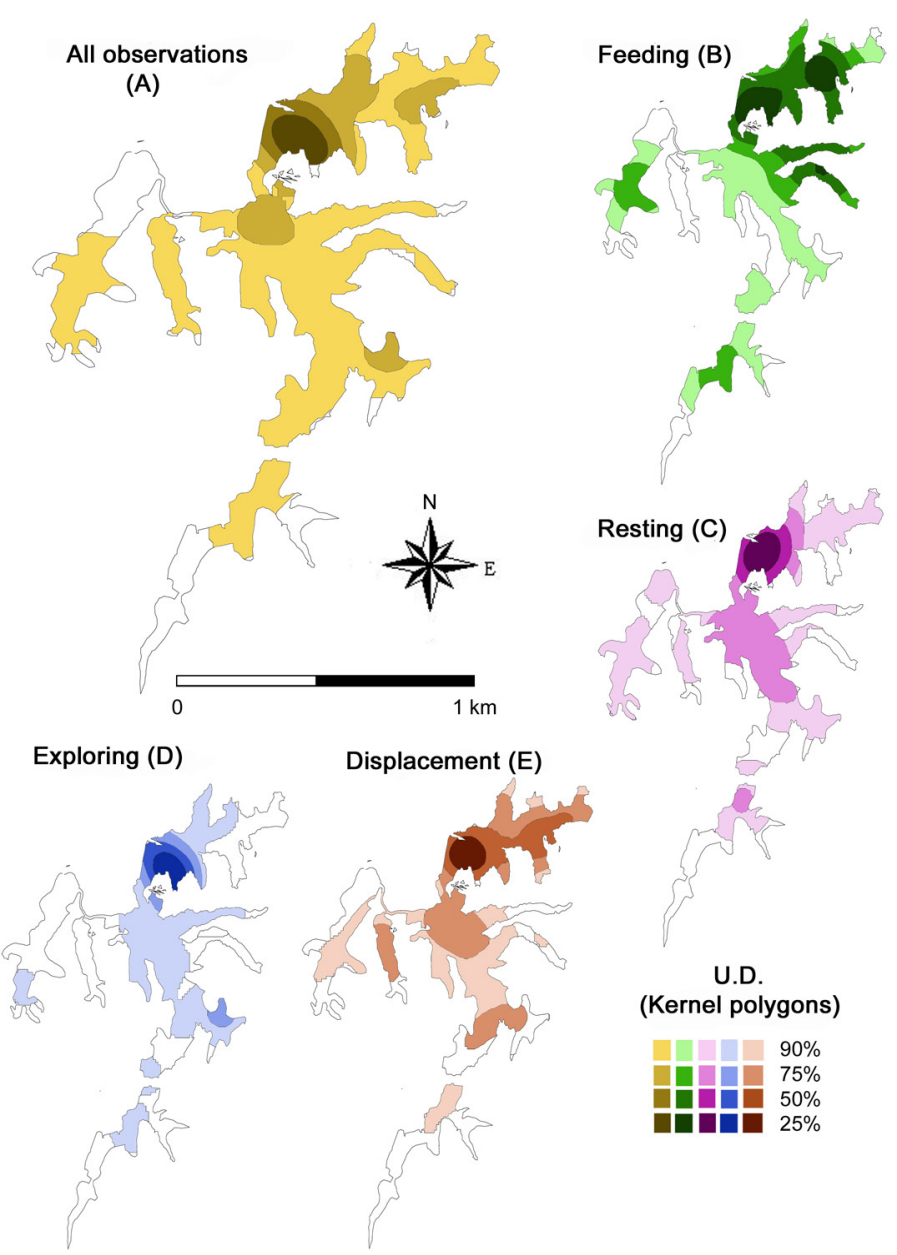

Figure 2. Utilization distribution (UD) by four manatees radio-tagged with a VHF system in Laguna de las Ilusiones, Villahermosa, Tabasco, Mexico, between April and August 2007. UD polygons were calculated by Kernel densities of the locations recorded during the study for all observations (A), and for each of the general behaviors observed (B-E)
18:00 to 0:00 $\mathrm{h}$ to cover the hours after sunrise and sunset. Some authors (Colmenero and Hoz 1986; Jiménez 1999; Jiménez 2002, Horikoshi-Becket and Shulte 2006) have reported that in sites with high human activity, the activity of manatees peaks in the twilight hours. The tracking of each individual and the tracking timetable were determined at random before each session. In each session, we recorded direct ad-libitum observations (Altmann 1974) of the general behavior exhibited by animals: feeding, resting, exploration and displacement. The position of each animal was recorded with a GPS (Garmin Etrex 10, Ltd. Kansas). Using the focal individual method, the presence of other individuals (tagged and untagged) was also recorded, along with data on the characteristics and conditions of the habitat (Hartman 1979; Axis-Arroyo et al. 1998; Jiménez 2005; Olivera-Gómez and Mellink 2005).

Characteristics of the Habitat: Water depth and temperature were recorded directly from a sonar unit (Humminbird 686C IF Eufala, Alabama). The distance to the nearest shore was estimated using a digital distance meter (Truepulse 200, Laser Technology, Inc., Colorado). The presence and percentage of occurrence of trees and wetland vegetation was determined within a $50 \mathrm{~m}$ radius from the site where the individual was located. The percentage of cloud cover was estimated visually. Rain was recorded as nil; light; short-term and heavy; and persistent heavy. Finally, the state of water was estimated according to the first four categories in the modern Beaufort scale (World Metereological Organization 2012): 0) calm water, like a mirror; 1) ripples with appearance of scales, no foam crests; 2) small wavelets, crests of glassy appearance, not breaking; 3 ) large wavelets, crests begin to break.

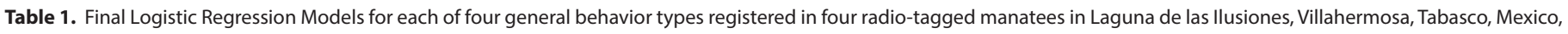
between April and August 2007. The best models are in bold. AICc = Akaike Information Coefficient for small samples; $\triangle \mathrm{AICc}=$ increase in AICc .

\begin{tabular}{|c|c|c|c|c|c|}
\hline Model & Nil Dev./Res. Dev.* & $\mathbf{K}$ & AICc & $\triangle \mathrm{AICc}$ & $\exp \left(\left(A I C_{\min }-A I C_{i}\right) / 2\right)$ \\
\hline \multicolumn{6}{|l|}{ Feeding } \\
\hline Depth + distance to the shore + tree cover + wind speed & 0.31 & 4 & 66.38 & & \\
\hline Depth + distance to the shore + tree cover + wind speed + association & & 8 & 66.74 & -0.357 & 0.836 \\
\hline Depth + distance to the shore + tree cover & & 3 & 72.21 & -5.828 & 0.054 \\
\hline \multicolumn{6}{|l|}{ Resting } \\
\hline Distance to the shore + tree cover + Association & 0.89 & 6 & 271.48 & & \\
\hline Association + tree cover & & 5 & 272.00 & -0.525 & 0.769 \\
\hline Distance to the shore + tree cover + water condition + association & & 10 & 272.28 & -0.807 & 0.668 \\
\hline \multicolumn{6}{|l|}{ Exploration } \\
\hline Association + depth & 0.97 & 5 & 310.98 & & \\
\hline Depth + association + water condition & & 9 & 311.95 & -0.969 & 0.615 \\
\hline Depth + water condition & & 5 & 312.21 & -1.230 & 0.541 \\
\hline \multicolumn{6}{|l|}{ Displacement } \\
\hline Depth + cloudiness + human activity & 0.90 & 5 & 325.69 & & \\
\hline Depth + human activity & & 4 & 327.07 & -1.380 & 0.501 \\
\hline Depth & & 1 & 333.15 & -7.460 & 0.024 \\
\hline
\end{tabular}

* Null Deviance/Residual Deviance, proportion of the deviance explained by the final model 

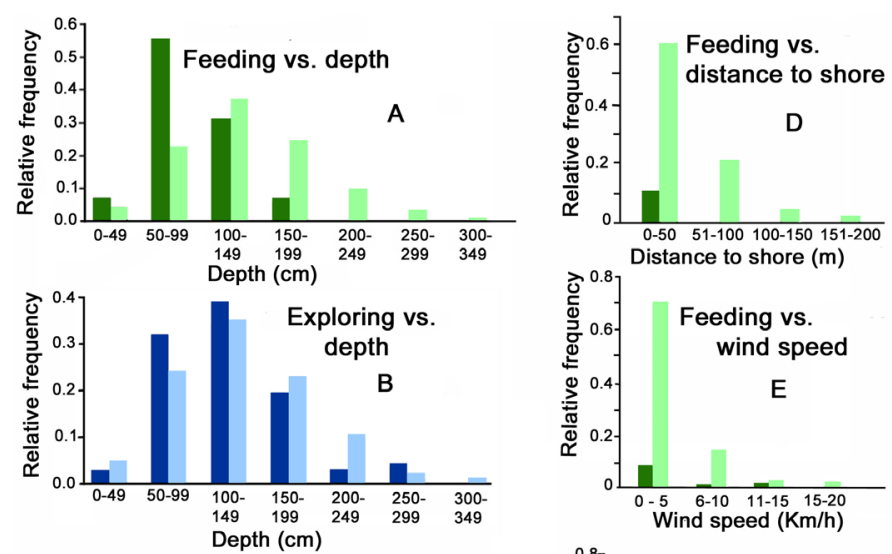

Wind speed $(\mathrm{Km} / \mathrm{h})$
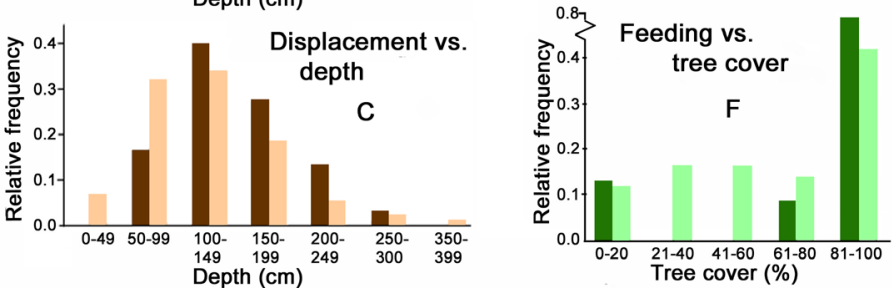

Figure 3. Distribution of the variables that were significant in the final Logistic Regression models for feeding, exploration and displacement recorded in radio-tagged manatees in this study at Laguna de las Ilusiones, Villahermosa, Tabasco, Mexico, between April and August 2007. Black bars are the number of sites where the behavior was observed, and white bars are the number of sites where the behavior was not observed.

Anthropogenic activity: This was recorded considering three categories: 1) nil, no activity; 2) medium, when there was spatial coincidence of manatees with any human activity or disturbance (for example, passing or presence of boats, fishing activities and human activities on the shore), and 3) high, when the activity leads to a reaction on the manatee, either by distancing from the human activity or by modifying its own activity.

Use of space. Polygons were built considering percent distribution levels of 25, 50, 75 and $95 \%$, named as utilization distribution (UD). Polygons were built with Kernel's fixed procedure (Worton 1989) in the Animal Movement extension (Hooge and Eichenlaub 1997) in Arc View 3.3 (Environmental System Research Institute, Inc., California, 2002). UD was calculated using the first position where an individual manatee was found during a tracking session. Other positions were included in the same session when more than three hours passed from the first observation, or when the animal changed its location in more than $100 \mathrm{~m}$.

Usage model and habitat selection versus characteristics of the habitat. By means of a step-by-step binary logistic regression with the Program $R$ (R Core Team 2013), considering the change that occurs with the maximum likelihood at each step as criterion to include or exclude variables in the model.

Activity and association with other individuals. Changes in activities between the selected periods of time were estimated with a Kruskal-Wallis test adjusted for ties (ZAR 1986). The mean proportion of time corresponding to each behavior observed was recorded for each sampling session. Cole's simple association coefficient $C_{7}$ (Cole 1949) was used to explore the spatial association between tagged individu- als, and between tagged individuals and other individuals in the population. $C_{7}$ values higher than 0.5 were considered as statistically significant (Bauman 1998).

\section{Results}

Manatees were tracked for a total of $174 \mathrm{~h}$ in the various lake environments, with an effective direct observation time of $113 \mathrm{~h}$, which results in an effort/observation rate of $65 \%$. The time dedicated to each individual was about 30 $\mathrm{h}$, except for the young male, for whom only $20 \mathrm{~h}$ of observation were recorded. With regard to the use of space, the $95 \%$ Kernel polygon (home range) includes $80 \%$ of the total lake area, while the $50 \%$ Kernel polygon (core range) shows that manatees used only $6 \%$ of the area during the dry season, focusing on the northern portion (Figure 2A).

The core areas ( $50 \%$ Kernel polygons) of the different behaviors overlap (Figures $2 \mathrm{C}, 2 \mathrm{D}$ and $2 \mathrm{E}$ ), but feeding and resting areas are more extensive and distinctive areas. Displacement entails broader and targeted movements relative to exploration, and indeed produced the most extensive core area. The feeding core area ( $n=29$ observations) was located to the north and east of the lake (Figure 2B), while resting $(n=55)$, displacement $(n=104)$ and exploration $(n=69)$ core areas are located exclusively in the northern portion of the lake.

The significant variables in the final logistic regression models are shown in Table 1. As regards feeding, four variables accounted for most of the variation: depth, distance to the shore, tree cover and wind speed. The resting behavior was partially explained by the presence of other individuals (company) and tree cover. Exploration was best modeled using depth, distance to the shore and company. Finally, for displacement, the variables in the best model included depth, cloudiness and human activities.

The distribution of observations for the variables in the best model is shown in Figures 3 and 4). Depth is a key variable, because it occurs in the best models for three of the four behaviors evaluated; feeding was observed in shallower areas compared to exploration or displacement (0.5 to $1.5 \mathrm{~m}$ depth; Figures $3 \mathrm{~A}, 3 \mathrm{~B}$ and $3 \mathrm{C}$ ). Feeding was affected to a lesser extent by distance to the shore or wind speed (Figures 3D and 3E). The manatees observed fed more frequently in areas with high tree cover (Figure 3F).

The resting behavior was negatively associated with company (Figure 4A), and was recorded mainly in areas of intermediate tree cover, avoiding areas that were either

Table 2. Association (Cole Index $C_{7}$ ) between radio-tagged manatees (between them and with other non-tagged individuals) in Laguna de las llusiones, Villahermosa, Tabasco, Mexico between April and August 2007.

\begin{tabular}{lcccc}
\hline \multicolumn{1}{c}{ Individual } & $\begin{array}{c}\text { Male } \\
\mathbf{1 8 0} \mathbf{~ c m}\end{array}$ & $\begin{array}{c}\text { Female } \\
\mathbf{2 0 3} \mathbf{~ c m}\end{array}$ & $\begin{array}{c}\text { Female } \\
\mathbf{1 9 5} \mathbf{~ c m}\end{array}$ & $\begin{array}{c}\text { Female } \\
\mathbf{2 8 5} \mathbf{~ c m}\end{array}$ \\
\hline Female $203 \mathrm{~cm}$ & 0 & & & \\
Female $195 \mathrm{~cm}$ & 0.020 & 0.064 & & \\
Female $285 \mathrm{~cm}$ & 0 & 0.440 & 0 & \\
Other individuals & 0.528 & 0.208 & 0.019 & 0.130 \\
\hline
\end{tabular}


open (Figure 4B) or close to the the shore (4C). With respect to displacement movements, a positive association with low cloud cover (Figure 4D) and low human activity (Figure $4 \mathrm{E})$ was noted; displacement also occurs in sites of intermediate depth (Figure 3C). Exploration is the most frequent behavior at intermediate depths (50 to $199 \mathrm{~cm}$, Figure 3B), and when animals were accompanied by other manatees (Figure 4F).

The distribution of records (median, interquartile interval, and UD interval) for each general activity with regard to the three periods of time in the study was as follows: the resting behavior differs between the three observation periods $(H=6.68, P=0.035)$. Animals rested less between 18:00 and 00:00 h. Exploration was not significantly different between observation periods $(H=1.55, P=0.461)$. Displacement took place mainly in the morning period $(\mathrm{H}=$ $7.55, P=0.023)$, and decreased in the afternoon. Feeding showed the opposite trend, occurring primarily in the afternoon $(H=9.85, P=0.007)$. Avoidance of boats and other human activities were recorded occasionally, with no differences between observation periods $(H=2.73, P=0.420)$.

The manatees tracked were accompanied by at least one other individual for $53 \%$ of the observation time. The only statistical association occurred between the young male and other non-tagged individuals $\left(C_{7}=0.58\right.$, Table 2$)$. The 203 and $285 \mathrm{~cm}$ long females were frequently together,
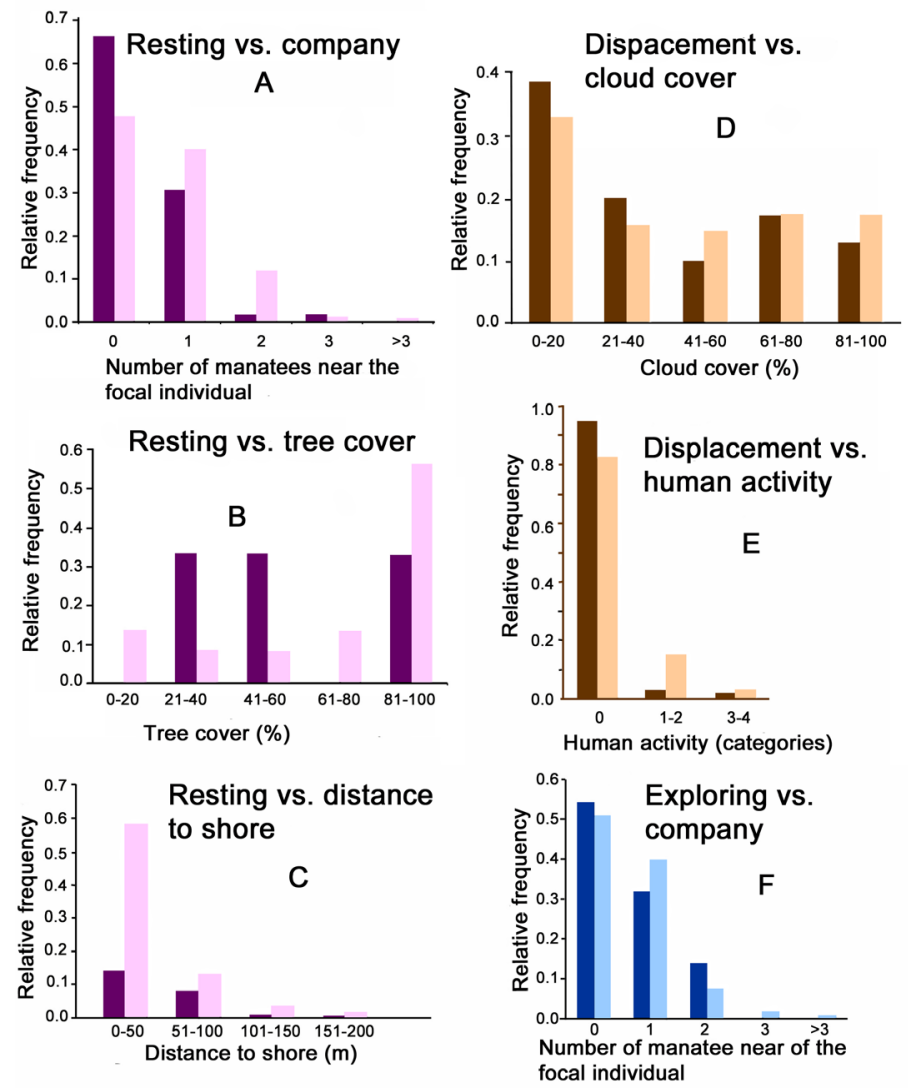

Figure 4. Distribution of the variables that were significant in the final Logistic Regression models for resting, exploration and displacement recorded in radio-tagged manatees in this study at Laguna de las Ilusiones, Villahermosa, Tabasco, Mexico, between April and August 2007. Black bars are the number of sites where the behaviour was observed, and white bars are the number of sites where the behavior was not observed. but the association between them was not significant $\left(C_{7}=\right.$ 0.44) as per Bauman (1998). The $195 \mathrm{~cm}$ long female was the most independent manatee.

\section{Discussion}

Aerial surveys and other methods used for the detection, counting and recording the behavior of manatees are impractical; as a result, details on the biology and ecology of the species in these ecosystems are little known (Marsh et al. 2012). The characteristics of the habitat in Laguna de las llusiones change as water level increases with the advent of the rainy season. Under the dry conditions that prevailed throughout the study, the perennial wetland vegetation (the major food source for manatees in the lake) occurred in just $14 \%$ of its shores. There are mango trees in $48 \%$ of the lake margins, and the dry season coincided with the availability of mango fruits. The 2007 dry season showed an atypical duration in the region, spanning until early September; consequently, manatee behavior was recorded under unusually dry conditions. The results obtained indicate that manatees occur in almost the entire lake, with their core areas $(50 \%$ Kernel polygons; Storline 2006; Roux and Bernard 2007) located in the northern portion of the lake. This area includes an arm of the lake connected with the central area by a narrow canal approximately $50 \mathrm{~m}$ wide that was very shallow, displaying a depth of less than $50 \mathrm{~cm}$ throughout the study. These conditions restrict the movements of manatees in or out of the northern area, as manatees avoid depths of less than $50 \mathrm{~cm}$ (Hartman 1979).

Previous studies recorded more sightings in the northwest area of the lake, a zone with less boat traffic, less activity on the lake shores and a broader plant cover (PabloRodríguez and Olivera-Gómez 2012). These findings contrast with ours, partly due to the difference in the method used, but also because the depth near the shore in that area was approximately $0.3 \mathrm{~m}$ and manatees could not easily reach the vegetation. It has been recorded that manatees are able to feed in areas where the depth is at least $0.5 \mathrm{~m}$ (Hartman 1979).

The northern area of the lake has more mango trees and it is where manatees have been observed feeding more frequently. This contributes to explain why manatee activities were concentrated in this area. The presence, time spent and movements of mantees are often associated with food availability (Montgomery et al. 1981; Jiménez 2005). In addition, this area shows little movement of boats, so that the avoidance of stress caused by a high rate of encounters with humans may have made tagged animals choose this area.

In this study, it was observed that the areas of general activity overlapped spatially, as these activities did not take place in different sites. This supports the idea that factors such as low depths at the entrance to the northern area of the lake probably restricted the movements of manatees in some areas. However, individuals were occasionally located in other areas, returning to the northeast area a few days 


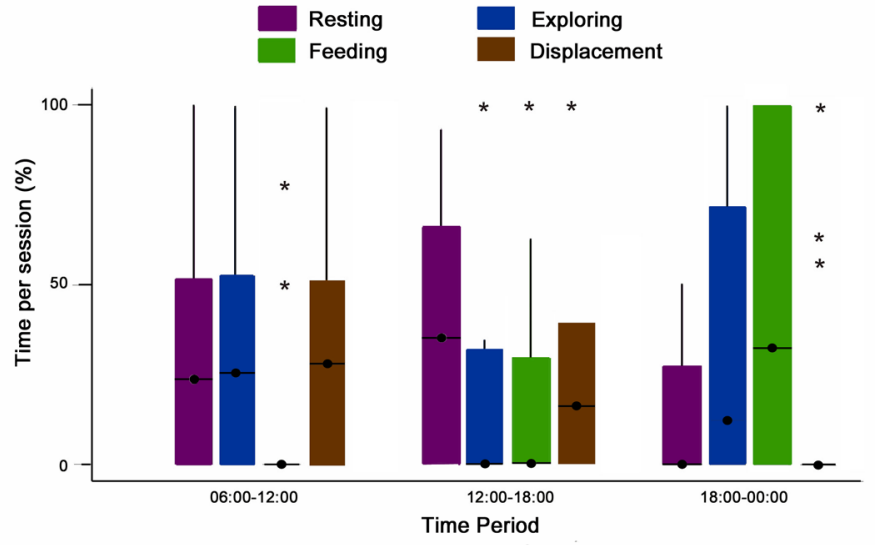

Figure 5. Distribution (median, interquartile range and range, ${ }^{*}=$ extreme data) of the general activities analyzed in the study, carried out by radio-tagged manatees in Laguna de las Ilusiones, Tabasco, Mexico, from April to August 2007.

later. Manatees may also have concentrated their activities within the same area to minimize the energy expenditure associated with displacement.

Manatees showed frequent movements in shallow waters along the lake shores, swimming through the deepest central area to go directly to other shores, as recorded in Florida (Hartman 1979). Manatees spent time in specific areas, making slow movements associated with exploration, resting or feeding. Exploration and displacement were the behaviors observed most frequently in the study, as reported by Pablo-Rodríguez and Olivera-Gómez (2012). In this sense, Bailey et al. (1996) point out that, in general, when food is scarce and sparse, large herbivores spend more time moving across patches, instead of staying in a single patch. Dugong dugon actively avoids feeding in a single patch of vegetation and moves randomly to other patches, abandoning the feeding patches; this behavior results in a faster recovery of the vegetation after disturbance (Preen 1993), so that exploration and displacement are frequent activities.

Our logistic regression model shows that depth, tree cover, company and distance from the shore explain the greatest portion of the variance. In this study, manatees used less deep areas for feeding than for performing another activity (Figure $3 \mathrm{~A}$ ). Wetland vegetation is more abundant in shallow gentle-sloping shores, although manatees that avoid shallow areas can feed in deep waters, where the slope allows them to move quickly toward deeper areas (Hartman 1979, Olivera-Gómez and Mellink 2005). In the case of the tree cover, trees provide shade, in addition to leaves, flowers and fruits that are usually consumed (O'Shea 1986). Forested patches in urbanized areas are associated with the shore vegetation and other plants, which would explain the importance of this variable in the feeding model. In the necropsy of one female (2005), large amounts of mango seeds were found throughout the digestive tract (Olivera-Gómez, pers. obs.). This seasonal focus on specific resources has also been reported elsewhere (Hartman 1979; Montgomery et al. 1981).

The logistic regression model showed a poor goodness of fit for the resting, exploration and displacement behaviors (Table 1). During these activities, manatees behave with relative independence of the characteristics of the habitat, as reported by Hartman (1979) and Reynolds (1981). On the other hand, there may be other variables that were not taken into account and which could help to explain the occurrence of these activities.

This study showed a significant effect of the time of the day on displacement, resting and feeding. Manatees showed the displacement behavior mostly during the morning and decreased this activity in the afternoon, as they were more sedentary and spent more time feeding. The resting behavior also increased during the afternoon. Manatees have been described as arrhythmic (Hartman 1979; Reynolds, 1981), although in areas with marked human activity, they seem to be more active at dawn, dusk and during nighttime (Colmenero and Hoz 1986; Jiménez 1999; Jiménez 2002; Horikoshi-Becket and Shulte 2006). While studying animals in captivity, Holguin et al. (2015) found a circadian cycle of the resting behavior, with manatees being more active during the day, which is consistent with other studies of manatees in captivity (Hénaut et al. 2010, Kikuchi et al. 2010).

The main source of food in the lake is the vegetation on the shores; furthermore, manatees might avoid feeding on grasses during the hours of high temperature to avoid problems associated related to post-gastric digestion (Reynolds and Rommel 1996). Instead, manatees may search for fresher materials such as fruits or leaves that are submerged, as was ocassionally observed. This study found that during almost half the observation time, animals were accompanied by at least one other individual. Hartman (1979) and Reynolds (1981) observed that manatees tend to be associated with one another when using a particular resource food, in this case - and move apart afterwards, a behavior that Reynolds (1981) described as social facilitation.

Implications for conservation. The behavior of manatees was influenced by seasonal conditions and human activities. The latter may exert not only a direct influence, but also through the modification of the habitat, as by clearing wetland vegetation. Recreational vessels, the management of floating plants and patrolling in response to illegal fishing and filling has increased. Rapid motor vessels are also a potential threat for manatees in this shallow lake, especially when animals gather together due to occasional restrictions, as in the case of this study. On several occasions we noted that manatees did not react to vessels that passed near them. In thermal shelters located in Florida, manatees have become adapted to the presence of vessels, but modify their distribution range by increasingly occupying areas restricted to vessels (Buckingham et al. 1999).

If the plant cover in the lake is reduced by urbanization, there will be a noticeable effect on manatees, especially under atypical conditions such as those observed in the study, which makes the conservation of the lake shores a top priority. The northwest area of the lake has a margin 
with an extensive plant cover; perhaps the depth could be increased in this area through dredging. An intensive management of the lake, its shores and its users should be undertaken, to develop strategies that contribute to ensure environmental conditions suitable for manatees.

\section{Acknowledgments}

The Universidad Juarez Autónoma de Tabasco and PROMEP (Program for the Improvement of Lecturers 103.5/04/2582). The Board of Natural Resources and Environmental Protection of Tabasco allowed working within the State Protected Area of Laguna de las llusiones. The capture and handling of manatees was conducted under special scientific collection license granted by the General Direction of Wildlife at SEMARNAT: SGPA/DGVS/01103/07. Y. Hénaut, D. Gonzalez and B. Morales provided useful comments for conducting this work. CONACYT, Mexico, granted a postgraduate scholarship to the first author. The comments of anonymous reviewers of this manuscript are also appreciated.

\section{Literature cited}

Altmann, J. 1974. Observational study of behavior: sampling methods. Behaviour 49:227-265.

Axis-Arroyo, J., B. Morales-Vela, D. Torruco-Gómez, and M. E. VegaCendejas. 1998. Variables asociadas con el uso de hábitat del manatí del Caribe (Trichechus manatus), en Quintana Roo, México (Mammalia). Revista de Biología Tropical 46:791-803.

Bailey, D. W., J. E. Gross, E. A. LacA, L. R. Rittenhouse, M. B. Coughenour, D. M. Swift, and P. L. Sims. 1996. Mechanisms that result in large herbivore grazing distribution patterns. Journal of Range Management 49:386-400.

Bauman, P. J. 1998. The Wind Cave National Park elk herd: home ranges, seasonal movements, and alternative control methods. M. S. Thesis. South Dakota State University. Brookings, U. S. A.

Buckingham, C. A., L. W. Lefebvre, J. M. Schaefer, and H. I. Kochman. 1999. Manatee response to boating activity in a thermal refuge. Wildlife Society Bulletin 27:514-522.

Castelblanco-Martínez, D. N., J. Padilla-Sáldivar, H. A. HernándezArana, D. Slone, J. P. Reid, and B. Morales-Vela. 2013. Movement patterns of Antillean manatees in Chetumal Bay (Mexico) and coastal Belize: A challenge for regional conservation. Marine Mammal Science 29:166-182.

CoLE, L. C. 1949. The measurement of interspecific association. Ecology 30:411-424.

Colmenero, R. C., And E.Z. Hoz. 1986. Distribución de los manatíes, situación y su conservación en México. Anales del Instituto de Biología, UNAM. México, Serie Zoología 56:955-1020.

CONANP. 2010. Programa de Acción para la Conservación de la Especie: Manatí (Trichechus manatus manatus). Compilado por Olivera Gómez, L. D., A. Ortega-Argueta, B. Morales Vela, and L. C. Colmenero Rolón. Comisión Nacional de Áreas Naturales Protegidas, SEMARNAT. Ciudad de México, México. Deutsch, C. J., J. P. Reid, R. K. Bonde, D. E. EAston, H. I. Kochman, AND T. J. O'SHEA. 2003. Seasonal movements, migratory behavior, and site fidelity of West Indian manatees along the Atlantic coast of the United States. Wildlife Monographs 151:1-77.
Estrada-Loreto, F., E. Barba-Macías, and R. Ramos-Reyes. 2013 Cobertura temporal de los humedales en la cuenca del Usumacinta, Balancán, Tabasco, México. Universidad y Ciencia 29:141-151.

Gannon, J., K. M. Scolardi, J. E. Reynolds III, J. K. Koelsch, and T. J. KESSENICH. 2007. Habitat selection by manatees in Sarasota Bay, Florida. Marine Mammal Science 23:133-143.

HARTMAN, D. S. 1979. Ecology and Behavior of the Manatee (Trichechus manatus) in Florida. American Society of Mammalogist, Special Publication No. 5. Lawrence, Kansas.

Hénaut, Y., S. P. Becerra-López, s. Machkour-M'rabet, B. MoralesVela, P. Winterton, and F. Delfour. 2010. Activities and social interactions in captive Antillean manatees in México. Mammalia 74:141-146.

Holguín-Medina, V. E., J. Fontenele-Araujo, V. M. Alcaraz-Romero, J. F. Cortes, And J. Muñoz-Delgado. 2015. Circadian and ultradian activity rhythms in manatee (Trichechus manatus manatus) in captivity. Biological Rhythm Research 46:631-645.

HOOGE, P. N., AND B. EICHENLAUB. 1997. Animal movement extensions to Arcview, Version 2.0 Alaska Science Center-Biological Science Office, U.S. Geological Survey. Anchorage, U. S. A.

Horikoshi-BeCKett, C., AND B. A. Schulte. 2006. Activity patterns and spatial use of facility by group of captive female manatees (Trichechus manatus latirostris). Zoo Biology 25:285-301.

INEGI. 2010. Censo de Población y Vivienda. Disponible en: http://www3.inegi.org.mx/sistemas/mexicocifras/default. aspx?e = 27. Consulted: January 19, 2016.

JIMÉNEZ, I. 1999. Estado de conservación, ecología y conocimiento popular del manatí (Trichechus manatus) en Costa Rica. Vida Silvestre Neotropical. 8:18-30.

JIMÉNEZ, I. 2002. Heavy poaching in prime habitat: the conservation status of the West Indian manatee in Nicaragua. Oryx. 36:272-278.

JIMÉNEZ, I. 2005. Development of predictive models to explain the distribution of the West Indian manatee Trichechus manatus in tropical watercourses. Biological Conservation 125:491-503.

KIKuCHI, M., V. M. F. Da Silva, F. C. Rosas, and N. Miyazaki. 2010. Application of acceleration data loggers to classify the behavior of captive Amazonian manatees (Trichechus inunguis). Coastal Marine Science. 34:24-30.

KoELSCH, J. 1997. The seasonal occurrence and ecology of Florida manatees (Trichechus manatus latirostris) in coastal waters near Sarasota, Florida. Master Thesis, University of South Florida. Sarasota, U. S. A.

Lefebvre, L. W., J. P. Reid, G. B. Rathbun, and D. P. Domning. 2001. Status and biogeography of the West Indian manatee. Pp. 425-474 in Biogeography of the West Indies: new patterns and perspectives. (Woods, C. A., and F. E. Sergile, eds.). CRC Press. Boca Raton, U. S. A.

Marsh, H., T. J. OsheA, AND J. E. Reynolds III. 2012. Ecology and Conservation of the Sirenia, Dugongs and Manatees. Cambridge University Press. New York, U. S. A.

MontgomerY, G. G., R. C. Best, AND M. YAMAKOSHI. 1981. A radiotracking study of the Amazonian Manatee Trichechus inunguis (Mammalia:Sirenia). Biotropica 13:81-85.

Morales-López, M., L. D. Olivera-Gómez, and C. E. ZentenoRuIz. 2012. Intervalo respiratorio y desplazamientos de 
manatíes Antillanos Trichechus manatus manatus (Sirenia). Comparación entre las temporadas seca y lluviosa en una laguna aislada. Mastozoologia Neotropical 19:117-126.

Olivera-Gómez, L. D., And E. Mellink. 2005. Distribution of the Antillean manatee (Trichechus manatus manatus) as a function of habitat characteristics, in Bahía de Chetumal, México. Biological. Conservation 121:127-133.

O'SHeA, T. J. 1986. Mast foraging by West Indian manatee (Trichechus manatus). Journal of Mammalogy 67:183-185.

Pablo-Rodríguez, N., and L. D. Olivera-Gómez. 2012. Situación de una población aislada de manatíes Trichechus manatus (Mammalia: Sirenia:Trichechidae) y conocimiento de la gente, en una laguna urbana, en Tabasco, México. Universidad y Ciencia 28:15-26.

Pérez-Garduza, F. 2013. Evaluación de la eficiencia de cuatro técnicas para determinar la abundancia de manatíes Trichechus manatus en ambientes poco visibles. Tesis de Maestría. Universidad Juárez Autónoma de Tabasco. Villahermosa, México.

PreEn, A. R. 1993. Interactions between dugongs and seagrasses in a subtropical environment. Ph. D. Dissertation, James Cook University. Townsville, Australia.

R CoRE TEAm. 2013. R: A language and environment for statistical computing. R Foundation for Statistical Computing, Vienna, Austria. Disponible en: http://www.R-project.org/. http:// www.r-project.org. Consulted: March 17, 2015.

RATHBUN, G. B., J. P. REID, AND J. BOURASSA. 1987. Design and construction of a tethered, floating radio tag assembly for manatees. Report prepared by U. S. Fish and Wildlife Service, Denver Wildlife Research Center, Gainesville Field Station. NTIS Doc. No. PB87161345. Avalilable at: leon_olivera@yahoo.com.mx

Reep, R. L. And R. K. Bonde. 2006. The Florida Manatee, Biology and Conservation. University Press of Florida. Gainesville, U. S. A.

REYNolds, J. E. III. 1981. Aspects of the social behavior and herd structure of a semi-isolated colony of West Indian manatees, Trichechus manatus. Mammalia 45:431-451.

ReYnolds, J. E., AND S. A. Rommel. 1996. Structure and function of the gastrointestinal tract of the Florida Manatee, Trichechus manatus latirostris. Anatomical Records 245:539-558.

Roux, C., AND R. T. F. Bernard. 2007. Home range size, spatial distribution, and habitat use of elephants in two enclosed game reserves in the Eastern Cape Province, South Africa. African Journal of Ecology 47:146-153.

Self-Sullivan, C., and A. Mignucci-Giannoni. 2008. Trichechus manatus ssp. manatus. En: IUCN (2011) IUCN Red List of Threatened Species Versión 2011.2. Disponible en: http:// www.iucnredlist.org. Consulted: March 7, 2016.

Sheppard, J. K., H. Marsh, R. E. Jhones, and I. R. Lawler. 2010. Dugong habitat use in relation to seagrass nutrients, tides and diel cycles. Marine Mammal Science 26:855-879.

Smith-Cavros, E. M., S. Duluc-Silva, M. C. Rodriguez, P. Ortiz, and E. O. KEITH. 2012. You can't eat money when you are hungry": campesinos, manatee hunting, and environmental regret in Veracruz, Mexico. The Journal of Culture and Agriculture 34:68-80.

Storline, J. T. 2006. Movements and habitat use of female Roosevelt elk in relation to human disturbance on the Hoko and Dickey game management units, Washington. Master Thesis. Faculty of Biology, Humboldt State University. Arcata, U. S. A.
World Meteorological Organization. 2012. Manual on Marine Meteorological Services. Volume I. WMO-No. 558. Geneva, Switzerland.

WORTON, B. J. 1989. Kernel methods for estimating the utilization distribution in home-range studies. Ecology 70:164-168.

$Z_{A R}$, J. H. 1986. Biostatistical Analysis, Second Edition. PrinceHall International. Englewood Cliffs, U. S. A.

Associated editor: Juan Pablo Gallo

Submitted: May 30, 2016; Reviewed: June 21, 2016;

Accepted: November 20, 2016; Published on line January 17, 2017. 